\title{
Cerebral oedema associated with hyponatraemia in renal failure
}

\author{
K. K. Arora \\ M.B., B.S., M.R.C.P. \\ JOANNA SHELDON \\ M.D., M.R.C.P.
}

\author{
M. J. BRUMmitT \\ M.B., B.S. \\ J. A. P. TRAFFord \\ M.B., M.R.C.P.
}

\section{Renal Unit, Royal Sussex County Hospital, Brighton, Sussex}

SuCCESSFUL treatment of cerebral oedema depends upon establishing its cause. We report the treatment of a case of presumed cerebral oedema, which appeared to have resulted from hyponatraemia.

\section{Case report}

A 47-year-old woman was admitted to the Royal Sussex County Hospital on 11 June 1968 in renal failure due to chronic pyelonephritis.

Investigations. $\mathrm{Hb} 52 \%$, WBC $7200 / \mathrm{m}^{3}$, blood urea $346 \mathrm{mg} / 100 \mathrm{ml}$, creatinine clearance $4.2 \mathrm{ml} / \mathrm{min}$, serum sodium $140 \mathrm{mEq} / \mathrm{l}$, calcium $8.0 \mathrm{mg} / 100 \mathrm{ml}$, phosphate $12.2 \mathrm{mg} / 100 \mathrm{ml}$, alkaline phosphatase 16.0 KA Units; urinary sodium $26 \mathrm{mEq} / 1$, potassium $22.3 \mathrm{mEq} / 1$, urea $870 \mathrm{mg} / 100 \mathrm{ml}$, albumin 0.02 $\mathrm{g} / 100 \mathrm{ml}$. A catheter specimen of urine cultured Ps. pyocyaneus and Esch. coli. Urinary output was 1-2 1/day. She responded well to treatment with peritoneal dialysis, sodium restriction and antibiotics.

In August 1968, however, she was readmitted in cardiac failure, conscious, but drowsy. Blood pressure $160 / 100 \mathrm{mmHg}$. Her investigations were as follows: blood urea $370 \mathrm{mg} / 100 \mathrm{ml}$, serum sodium $150 \mathrm{mEq} / \mathrm{l}$, potassium $5.0 \mathrm{mEq} / 1$, alkali reserve 10 $\mathrm{mEq} / 1$, urinary sodium $77 \mathrm{mEq} / 1$, potassium $6 \cdot 1$ $\mathrm{mEq} / 1$, urea $430 \mathrm{mg} / 100 \mathrm{ml}$, blood glucose $58 \mathrm{mg} / 100$ $\mathrm{ml}$. There was again a heavy growth of $P$ s. pyocyaneus in the urine. She was treated with peritoneal dialysis for 2 days, and she improved initially. Peritoneal dialysis was discontinued after 2 days. Thereafter, however, her serum sodium fell, and on the morning of the fourth day after admission it was $126 \mathrm{mEq} / \mathrm{l}$. During the evening she had grand mal fits and became deeply unconscious, and artificial ventilation was required. Her condition deteriorated rapidly, the pupils were fixed and dilated, and she developed papilloedema. At that time serum sodium was 122
$\mathrm{mEq} / 1$, potassium $5.0 \mathrm{mEq} / 1$; blood urea $150 \mathrm{mg} / 100$ $\mathrm{ml}$, alkali reserve $14 \mathrm{mEq} / \mathrm{l}$, and blood glucose 325 $\mathrm{mg} / 100 \mathrm{ml}$.

Treatment. An arterio-venous shunt was inserted and a litre of $2 \mathrm{~N}$ saline and $500 \mathrm{ml} 10 \%$ mannitol were given intravenously and 2.51 of fluid simultaneously removed by haemodialysis against a high venous pressure. She received a total of $875 \mathrm{mEq}$ of sodium over the next $24 \mathrm{hr}$.

By the following morning she was conscious and breathing spontaneously; the pupils reacted normally. Thereafter she made an uneventful recovery and has since done well on chronic intermittent haemodialysis and sodium supplements (she is a saltloser) for 2 years.

\section{Discussion}

Occasional patients with chronic renal failure, particularly those with pyelonephritis, may have high urinary sodium loss due to failure of sodium reabsorption. In such patients a low salt diet may result in hyponatraemia. Failure to recognize this situation may precipitate extracellular hyponatraemia with relative intracellular hyperosmolarity leading to a shift of water into the cells. Treatment was therefore directed towards reversing intracellular hyperosmolarity by extracting water from the cells to the extracellular compartment by means of infusion of hypertonic saline, expanding the plasma volume with mannitol $10 \%$ and finally removing water by haemodialysis against a high venous pressure. The rapid improvement in her condition with such a therapy suggested the above presumption may have been correct.

\section{Acknowledgment}

We are grateful to Miss Clayton for typing this paper. 